\title{
RESENHAS
}

\section{Cinematógrafo: um olhar sobre a História}

NÓVOA, Jorge. FRESSATO, Soleni Biscouto, FEIGELSON, Kristian (organizadores). Cinematógrafo: um olhar sobre a história. Salvador: EDUFBA, São Paulo: Ed. UNESP, 2009.

Karine Mileibe de Souza ${ }^{*}$

O cinema é a arte da luz, da imagem e do movimento, é a arte da expressão audiovisual. Geertz nos ensina que é difícil falar de arte, pois, "a arte parece existir em um mundo próprio, que o discurso não pode alcançar" e este preceito é válido para o cinema, conhecido como a sétima arte. Analisar uma arte que envolve imagem e movimento é uma tarefa complexa, pois "aquilo que vimos, ou que imaginamos ter visto, parece ser tão maior e tão mais importante que o que logramos expressar com nossa balbucia, que nossas palavras soam vazias, cheias de ar, até falsas." ${ }^{2} \mathrm{~A}$ imagem é captada e projetada por meio de um processo mecânico, através do olhar e do veículo condutor da câmera. A mensagem audiovisual é composta dentro de determinados parâmetros e preceitos da construção cinematográfica, na maioria das vezes de forma narrativa. Como observa Bertoni e Montagnoli:

\begin{abstract}
Elementos que trabalham com a expressividade da câmera, com os detalhes, com as mudanças de planos, os enquadramentos, o som, a possibilidade de sugestão daquilo que está dentro e fora do quadro; mas também com o corte que direciona a visão do espectador, com a articulação da montagem, a característica minimal do cinema, com a irrealidade construída. Enfim, todo esse conjunto de elementos e de procedimentos, traça a característica de construção fundamental da linguagem e da estética do cinema. ${ }^{3}$
\end{abstract}

Desta forma, o cinema pode ser um elemento de análise e reflexão sobre a produção de discursos, pois o cinema é um produto, representação, arte, expressão importante da cena contemporânea que faz parte da estrutura do poder simbólico. Desde que surgiu, em 1895, na Europa, o cinema

\footnotetext{
* Mestre em Educação, Cultura e Organizações Sociais pela Funedi/UEMG.

1GEERTZ, Clifford. O saber local: novos ensaios em antropologia interpretativa. Petrópolis: Vozes, 1997. P. 142.

2 Ibid. P. 143.

${ }^{3}$ BERTONI, Iris Gomes. MONTAGNOLI, Giuliano Miki. Cineastas pioneiros da história e da evolução cinematográfica. Caraguatatuba: Editora, Produtora e Atelier de Artes Tanzcine e Giurhis, 2007. P. 14.
} 
revolucionou a sociedade e a partir da década de setenta do século $X X$, os estudos de Marc Ferro propuseram uma série de questionamentos que mesclam história e filme. Como coloca o autor "desde que o cinema se tornou uma arte, seus pioneiros passaram a intervir na história com filmes, documentários ou de ficção, que, desde sua origem, sob a aparência de representação, doutrinam e glorificam."4 O cinematógrafo e a tecnologia de captura e reprodução de imagens produziu um extraordinário fenômeno de massas.

O livro Cinematógrafo. Um olhar sobre a História, não por acaso faz referência a este instrumento que nos possibilitou um novo olhar sobre 0 mundo. O livro reflete sobre a produção e reprodução de representações, as visões da história geradas em um filme e a relação entre estas representações e as ciências sociais. Afinal, como observa Deleuze:

O olhar imaginário faz do real algo imaginário, ao mesmo que, por sua vez, se torna real e torna a nos dar realidade. É como um circuito que troca, corrige, seleciona e nos persegue. ${ }^{5}$

O cinema vem sendo objeto de pesquisas por conta daquilo que suas relações com as sociedades podem nos revelar, já que o cinema pode ser um objeto de análise importante para uma abordagem social. O filme é um meio visual que dramatiza um enredo básico, lida com fotografias, imagens, linguagens e, através de signos, códigos, que pela leitura são apreendidos, nos passa uma mensagem.

Entre as linguagens da cultura midiática, o cinema e sua estrutura de comunicação de um discurso vem sendo objeto de várias análises e discussões. Segundo Ferro, existem múltiplas interferências e confluências entre cinema e história. O cinema pode ser usado como um agente da história, ou como forma de disseminação de um discurso acerca da história já que "uma imagem é também uma informação, como uma palavra, um texto escrito e um discurso." 6

\footnotetext{
${ }^{4}$ FERRO. Marc. Cinema e história. Rio de Janeiro: Paz e Terra, 1992. P. 13.

5 DELEUZE, Gilles. A imagem-tempo. São Paulo: Brasiliense, 2007. P. 33.

${ }^{6}$ FERRO. Marc. A quem pertence as imagens? In: NÓVOA, Jorge. FRESSATO, Soleni Biscouto, FEIGELSON, Kristian (organizadores). Cinematógrafo: um olhar sobre a história. Salvador: EDUFBA, São Paulo: Ed. UNESP, 2009. P. 16.
} 
A obra, organizada por Jorge Nóvoa, Soleni Biscouto Fressato e Kristian Feigelson reforça as pesquisas científicas entre pesquisadores franceses e brasileiros no domínio das relações entre o cinema e as sociedades que denominamos, a partir de Marc Ferro, de cinema-história. O prólogo, escrito por Ferro e intitulado "A quem pertence as imagens?" reflete sobre as múltiplas apropriações e leituras de uma imagem. O cinema e o sentimento por ele gerados são inseparáveis. Já que as imagens e os efeitos produzidos por elas estão diretamente relacionados à cultura de quem recebe o filme o autor conclui que "o filme pertence também aquele que o vê." 7

O livro reúne contribuições de pesquisadores em três áreas principais: os fundamentos teóricos da história e das ciências sociais e da representação dos processos históricos, a construção do passado no cinema e os filmes como lugar de memória e identidade que se cruzam no discurso fílmico. Segundo David Harvey, o cinema tem "talvez a capacidade mais robusta de tratar de maneira instrutiva de temas entrelaçados do espaço e do tempo." 8

Assim, o livro busca fundir abordagens históricas e sociológicas numa leitura transdisciplinar de seu objeto-problema a partir de um conjunto de suportes audiovisuais pouco abordados no Brasil. Tais estudos buscam aprofundar pistas abertas por Marc Ferro em seus estudos dos cruzamentos entre história e cinema, numa obra acessível a um grande público de pesquisadores, professores e estudantes de diversas áreas de pesquisa.

\section{BIBLIOGRAFIA}

1. BERTONI, Iris Gomes. MONTAGNOLI, Giuliano Miki. Cineastas pioneiros da história e da evolução cinematográfica. Caraguatatuba: Editora, Produtora e Atelier de Artes Tanzcine e Giurhis, 2007.

2. DELEUZE, Gilles. A imagem-tempo. São Paulo: Brasiliense, 2007.

3. FERRO. Marc. A A quem pertence as imagens? In: NÓVOA, Jorge. FRESSATO, Soleni Biscouto, FEIGELSON, Kristian (organizadores). Cinematógrafo: um olhar sobre a história. Salvador: EDUFBA, São Paulo: Ed. UNESP, 2009.

4. FERRO. Marc. Cinema e história. Rio de Janeiro: Paz e Terra, 1992.

5. FRESSATO, Soleni Biscouto. Cinematógrafo: pastor de almas ou o diabo em pessoa?In: NÓVOA, Jorge. FRESSATO, Soleni Biscouto, FEIGELSON, Kristian (organizadores). Cinematógrafo: um olhar sobre a história. Salvador: EDUFBA, São Paulo: Ed. UNESP, 2009.

\footnotetext{
7 Ibid. p. 23.

${ }^{8}$ HARVEY, David. Condição pós-moderna. São Paulo: Edições Loyola, 1992. P. 277.
} 
6. GEERTZ, Clifford. O saber local: novos ensaios em antropologia interpretativa. Petrópolis: Vozes, 1997.

7. HARVEY, David. Condição pós-moderna. São Paulo: Edições Loyola, 1992. 